\title{
Measuring of Regional Growth Performance using Shift Share Analysis with Special Reference to
} Sabaragamuwa Province, Sri Lanka

\author{
R.J.M. Uduporuwa \\ Department of Geography and Environmental Management \\ Faculty of Social Sciences and Languages \\ Sabaragamuwa University of Sri Lanka \\ Email: manohariuduporuwa@gmail.com
}

Sri Lanka

\section{ABSTRACT}

The Shift-Share analysis is an effective tool that is widely applied in regional economic research to understand regional growth change during a certain period. The objective of this paper is to review the recent growth performance of the Sabaragamuwa Province which is nine provinces in Sri Lanka, applying the Shift Share tool to give an insight into its growth performance for effective policy formulation. Employment data were taken for this analysis from the Annual Report of Sri Lanka Labour Force Survey conducted by the Department of Census and Statistics in the year 2013 and 2018 and Excel spreadsheets were used to perform the analysis. According to the statistics, the province has reported a negative change in employment during the period of 2013-2018 indicating a huge job loss. According to the Shift Share analysis, it is found that this job loss was primarily due to the unfavorable National Share (NS) since the overall national growth rate of the country was minus during this analysis period. The Industry Mix (IM) effect was considerably favorable since 70 percent of industries were able to increase their jobs. Agriculture is the main industry which lost a large number of jobs due to the declining trend of the agricultural sector at the national level. Results also show that the region is fairly competitive since its overall Regional Share (RS) value was positive representing a job-saving at the regional level. This job saving is due to the 40 percent of leading industries in the regions. Agriculture is the main industry sector which has performed well in the region. Results of the analysis suggest that a strong policy intervention both at the regional and the national level is essential to boost up the growth performance of the region.

\section{Keywords: Regional growth, Shift Share, National Share (NS), Industry Mix (IM), Regional Share (RS), Sabaragamuwa Province}

\section{Introduction}

Regional development is a very important and challenging task, especially for developing nations. Regional development is a broad term but, can be seen as a general effort taken to reduce regional disparities by supporting employment and wealth-generating economic activities in regions. Friedmann (1970) has stated that regional development concerns the 'incidence of economic growth' and it is ultimately a result of the 'location of economic activities' in response to different regional attractions. According to Capello (2009), regional development can be defined as the ability of a region to produce with a (comparative or absolute) advantage, the 'goods and service' demanded by the national and international economic system to which it belongs. In this way, all these definitions necessarily reveal that 'economic growth' is the fundamental condition of regional development. Regions with a strong economic growth performance become leading regions in a country and inevitably support the other dimensions of the regional development as well as the overall national development. Therefore, analysis of the economic performance of regions of a country from time to time is very much important to understand national and regional causes of changes in regional growth/decline and to guide the regional as well as national development policy-making process timely in an effective way.

In this sense, the objective of this paper is to review the recent (2013-2018) economic growth performance in the Sabaragamuwa Province which is one of the nine provinces in Sri Lanka by applying the Shift Share technique to give guidance for the preparation of appropriate regional policies for better economic performance in the region. Shift Share technique is one of the effective and widely used tools to explain changes in the economy of a region between two time periods. This method was first introduced by Daniel Creamer (Yasin, Alavi, Sobral, \& Lisboa, 2004) in the 
early 1940s but, was summarized and induced by Dunn in 1960. This technique is a frequently used and simple method to describe regional economic growth, to measure policy effects, and to forecast the future growth of a region (Mead and Ramsay 1982; Kurre and Weller 1989; Andrikopoulos, Bronx, and Carvalho 1990). This has been popular in the fields of regional economic, political economics, marketing, geography, regional science, health science, and urban studies for about four decades (Knudsen, 2002, Chun-Yun Shi and Yang Yang, 2008). Over time, many kinds of extended Shift Share models have been advanced and put into practice in economic studies. Shift Share analysis is a technically simple procedure and is not a costly and time-consuming activity in terms of data collection. It can be performed with data already collected which are generally accessible. Though it is technically simple, it can well reflect regional or industrial changes over time (Nazara \& Hewings, 2004). This analysis is used to describe the change occurring in terms of different economic variables such as Gross Domestic Product (GDP), income, expenditure, employment, and even crime and health statistics. This paper performs the Shift Share analysis with the employment statistics of 17 industry groups in the Sabaragamuwa Province, in Sri Lanka during the period of 2013 2018 .

Looking at the Sabaragamuwa Province it is one of the nine provinces in Sri Lanka located outer periphery of the country. (Samarasinghe 1984, Moor, 1984, Wijedasa, 1992, Wanasinghe, 2001). It covers an extent of 4968.2 Sq. $\mathrm{Km}$ of land area and it is 8 percent of the total land area of the country and consists of two administrative districts namely Rathnapura and Kegalle. The agro-climatic divergence in the province produces a wide range of agricultural products such as tea, rubber, coconuts, paddy, and other export crops, vegetables, and fruits. The economy of the Sabaragamuwa Province is predominantly agricultural consisting mainly of plantation and paddy cultivation including minor crops. According to the general land use of the Sabaragamuwa Province, nearly 76 percent of the area in the province is under agriculture. As in the case of other provinces in Sri Lanka, the industrial sector of the Sabaragamuwa Province is highly insignificant. The gem mining, gem cutting, and gem trading industry is one of the important sectors of the economy of the Province. Although Sabaragamuwa Province is rich in physical as well as human resources, according to most of the socio-economic indicators Sabaragamuwa Province is one of the slowgrowing regions in the country with a less contribution to Gross Domestic Product (GDP) in the country and a high poverty index (Wijerathna et al, 2014, Sabaragamuwa Provincial Council, 2018). In this context, reviewing its recent growth characteristics will give an insight into how it is performing and will be uttermost important for policymakers to determine the targets in regional development planning.

\section{Overview of the Shift Share Analysis}

Shift Share is a standard regional analysis method that attempts to determine how much of regional growth/decline can be attributed to national growth or decline and how much is due to unique regional factors. This analysis decomposes the change (growth or decline) in an economy over a specific period into mutually exclusive factors. It gives a picture of how well the region's current industries are performing by systematically examining the National Share (RS), Industry Mix (IM), and Regional Share (RS) of change in a selected variable. A Shift-Share analysis will provide a dynamic account of total regional growth/decline of the selected variable that is attributable to a change of the national economy, a mix of faster or slower than average growing industries, and the competitive nature of the local industries. In this analysis it is assumed by economic growth or decline of a region is a result of these three components.

\section{National Share (NS)Effect}

National Share (NS) is the national growth effect, explains how much of the regional industry's growth is explained by the overall health of the national economy of a country or in other words if the regional industry grew at the industry's national growth rate, what would be the result. If the nation's whole economy is growing, it is generally expected that a positive change happens in each industry in the local region like the well-known proverb which is "a rising tide lifts all boats". On the other, if the nation's whole economy is declining, it is generally expected that a negative change happens in each industry in the local region.

\section{Industry Mix (IM) Effect}

The industry mix effect represents the contribution made by the change in the jobs (this paper uses the employment data in different industries) in the industries at the national level to the change in the number of jobs in the region or share of regional growth or decline explained by both overall national trends and national trends in that specific industry. This estimates how many jobs were created or lost in each industry in the reference region due to 
the differences in each industry and total national growth rates. This measures the industry composition of the region, namely to what extent the region specializes in industries that are growing rapidly or slowly nationally. A region with a high concentration of high growth industries will have a positive industrial structure effect and a region with a high concentration of low growth industries will have a negative industrial effect. The industrial mix effect is calculated by applying the job growth of the industry at the national level to the same industry at the regional level. This is started by subtracting the national growth rate of the overall economy from the national growth rate of the specific industry. This gives a national industry premium which is an indication of how much that industry outperformed or underperformed the economy as a whole nationwide.

\section{Regional Share (RS) Effect}

Regional shift or the regional competitiveness effect is the most important of the three indicators, as it explains how much of the change in a given industry is due to some unique competitive advantage that the region possesses or a representation of how a region's competitive position can contribute to regional growth because the change in growth cannot be explained only by overall national growth trends or a mix of industries of an economy. This effect can be higher than actual job growth if national and/or industry mix effects are negative while regional growth is positive. This is because the regional competitiveness effect accounts for jobs "saved" from declining national trends as well as new jobs created. Regional Shift is usually attributed to some local comparative advantage such as natural resources, favorable local labor situations, local raw materials or local inputs, linked industries, transportation methods, local wage rates, the influence of local industries, university influences, local consumption, and savings, and other comparative advantages. This component helps in identifying a local area's economic strengths. It is also important to identify the large gainers or losers in the region. These industries are important to the local economy for job creation. Also, these industries are key to pulling in money from outside of the local region and thus have a multiplier effect. These industries will generate larger revenues in the long run because they are attracting money from outside of the regional workforce area as well as creating new jobs within the region.

The Shift Share model used for Sabaragamuwa Province is summarized in the following equation.

$\mathrm{SS}=\mathrm{NS}+\mathrm{IM}+\mathrm{RS}$

$\mathrm{SS}=$ Shift Share (Actual growth of the region)

NS = National Share

$\mathrm{IM}=$ Industry Mix

$\mathrm{RS}=$ Regional Share

The equations for each component are,

$\mathrm{NS}={ }_{\mathrm{i}}$ local $_{\mathrm{t}-1} *\left(\right.$ National $_{\mathrm{t}}-$ National $\left._{\mathrm{t}-1}\right) /$ National $_{\mathrm{t}-1}$

$\mathrm{IM}={ }_{\mathrm{i}}$ local $_{\mathrm{t}-1} *\left(\left({ }_{\mathrm{i}} \mathrm{National}_{\mathrm{t}}-{ }_{\mathrm{i}} \mathrm{National}_{\mathrm{t}-1}\right) /{ }_{\mathrm{i}} \mathrm{National}_{\mathrm{t}-1}-\left(\right.\right.$ National $\left.\left._{\mathrm{t}}-\mathrm{National}_{\mathrm{t}-1}\right) / \mathrm{National}_{\mathrm{t}-1}\right)$

$\mathrm{RS}={ }_{\mathrm{i}} \mathrm{local}_{\mathrm{t}-1} *\left(\left({ }_{\mathrm{i}}\right.\right.$ local $_{\mathrm{t}}-\mathrm{i}_{\mathrm{i}}$ local $\left.\left._{\mathrm{t}-1}\right) /{ }_{\mathrm{i}} \mathrm{local}_{\mathrm{t}-1}-\left({ }_{\mathrm{i}} \mathrm{National}_{\mathrm{t}}-{ }_{\mathrm{i}} \mathrm{National}_{\mathrm{t}-1}\right) /{ }_{\mathrm{i}} \mathrm{National}_{\mathrm{t}-1}\right)$

Where,

${ }_{\mathrm{i}}$ local $_{\mathrm{t}-1} \quad=$ Number of local jobs in an industry(i) at the beginning of the analysis period

ilocal $\quad=$ Number of local jobs in an industry(i) at the end of the analysis period

National $_{t-1}=$ Total number of jobs in the nation at the beginning of the analysis period

National $_{\mathrm{t}}=$ Total number of jobs in the nation at the end of the analysis period

${ }_{\text {iNational }} \mathrm{t}_{\mathrm{t}}=$ Number of jobs in the nation in an industry(i) at the beginning of the analysis period

${ }_{\text {iNational }}{ }^{t-1}=$ Number of jobs in the nation in an industry(i) at the end of the analysis period

\section{Data Source}

This analysis depends on the employment figures in the Sabaragamuwa Province and the entire country of Sri Lanka. In this regard, employment data were taken from the Sri Lanka Labor Force Survey which is one of the important and regular surveys with provincial and district level data conducted by the Department of Census and Statistics, Sri Lanka. Since the analysis focuses on the growth performance of the Sabaragamuwa Province during the last five-year period, the employment category and the statistics of the annual reports of Sri Lanka Labor Force Survey in the year 2013 and 2018 were used. Table 01 shows the number of jobs related to 17 categories of industries 
International Journal of Humanities and Applied Social Science (IJHASS)

E-ISSN: 2471-7576

October 2020, Vol: 5, Issue: 10

E-mail: editor@ijhassnet.com

http://ijhassnet.com/

DOI: 10.33642/ijhass.v5n10p1

CCenter for Promoting Education and Research (CPER) USA,www.cpernet.org

in the year 2013 and 2018, total job changes in number and percentage in the Sabaragamuwa Province, and the national economy.

Table 01: Employment change in industry groups in Sabaragamuwa Province and the National context, 2013-2018

\begin{tabular}{|c|c|c|c|c|c|c|c|c|}
\hline \multirow{2}{*}{ Industrial Sector } & \multicolumn{4}{|c|}{ Sabaragamuwa Province } & \multicolumn{4}{|c|}{ National Economy } \\
\hline & 2013 & 2018 & $\begin{array}{c}\text { Change in } \\
\text { number }\end{array}$ & $\%$ & 2013 & 2018 & $\begin{array}{c}\text { Change in } \\
\text { number }\end{array}$ & $\%$ \\
\hline $\begin{array}{l}\text { Agriculture, Forestry } \\
\text { and Fishery }\end{array}$ & 280662 & 284891 & 4229 & 1.51 & 2504310 & 2043698 & -460612 & -18.39 \\
\hline Mining \& Quarrying & 38340 & 31055 & -7285 & -19.00 & 100153 & 62136 & -38017 & -37.96 \\
\hline Manufacturing & 182516 & 154889 & -27627 & -15.14 & 1514039 & 1463919 & -50120 & -3.31 \\
\hline $\begin{array}{l}\text { Construction, } \\
\text { Electricity, Gas, steam } \\
\text { and air conditioning } \\
\text { supply, Water supply, } \\
\text { sewerage, waste } \\
\text { management and } \\
\text { remediation activities }\end{array}$ & 46422 & 70825 & 24403 & 52.57 & 587698 & 713207 & 125509 & 21.36 \\
\hline $\begin{array}{l}\text { Wholesale and Retail } \\
\text { Trade, Repair of } \\
\text { Motor Vehicles and } \\
\text { Motor cycles }\end{array}$ & 94339 & 94592 & 253 & 0.27 & 1150911 & 1141416 & -9495 & -0.82 \\
\hline $\begin{array}{l}\text { Transportation and } \\
\text { Storage }\end{array}$ & 56197 & 47687 & -8510 & -15.14 & 517511 & 502126 & -15385 & -2.97 \\
\hline $\begin{array}{l}\text { Accommodation and } \\
\text { food service activities }\end{array}$ & 14261 & 12565 & -1696 & -11.89 & 188219 & 238145 & 49926 & 26.53 \\
\hline $\begin{array}{l}\text { Information and } \\
\text { Communication }\end{array}$ & 3566 & 1174 & -2392 & -67.08 & 62640 & 55220 & -7420 & 13.27 \\
\hline $\begin{array}{l}\text { Financial and } \\
\text { Insurance activities }\end{array}$ & 6147 & 10564 & 4417 & 71.86 & 153027 & 173330 & 20303 & 13.27 \\
\hline $\begin{array}{l}\text { Professional Scientific } \\
\text { and technical activities }\end{array}$ & 4797 & 5543 & 746 & 15.55 & 67964 & 86286 & 59951 & 88.21 \\
\hline $\begin{array}{l}\text { Administrative and } \\
\text { support service } \\
\text { activities }\end{array}$ & 6442 & 10899 & 4457 & 69.19 & 107027 & 166978 & 59951 & 56.01 \\
\hline $\begin{array}{l}\text { Public administration } \\
\text { and defense } \\
\text { compulsory social } \\
\text { security }\end{array}$ & 42764 & 32910 & -9854 & -23.04 & 629288 & 434348 & -194940 & -30.98 \\
\hline Education & 31818 & 29191 & -2627 & -8.26 & 329572 & 425092 & 95520 & 28.98 \\
\hline $\begin{array}{l}\text { Human health and } \\
\text { social work }\end{array}$ & 14000 & 10571 & -3429 & -24.49 & 141020 & 142861 & 1841 & 1.31 \\
\hline $\begin{array}{l}\text { Other Service } \\
\text { Activities }\end{array}$ & 9524 & 7987 & -1537 & -16.14 & 131982 & 116733 & -15249 & -11.55 \\
\hline $\begin{array}{l}\text { Activities of } \\
\text { households as } \\
\text { employers; } \\
\text { undifferentiated goods } \\
\text { and services-providing } \\
\text { activities of } \\
\text { households for own } \\
\text { use }\end{array}$ & 32570 & 19759 & -12811 & -39.33 & 182277 & 194303 & 12026 & 6.60 \\
\hline Other & 2628 & 2897 & 269 & 10.24 & 49766 & 55368 & 5602 & 11.26 \\
\hline Total employment & 866993 & 827999 & -38994 & -4.50 & 8417404 & 8015166 & -402238 & -4.78 \\
\hline
\end{tabular}

Source: Annual Report of Sri Lanka Labor Force Survey, 2013, 2018 
International Journal of Humanities and Applied Social Science (IJHASS)

E-ISSN: 2471-7576

October 2020, Vol: 5, Issue: 10

E-mail: editor@ijhassnet.com

http://ijhassnet.com/

DOI: 10.33642/ijhass.v5n10p1

CCenter for Promoting Education and Research (CPER) USA,www.cpernet.org

\section{Results and Discussion}

Looking at the employment change that happed in the reference period in the Sabaragamuwa Province as an approach to the result review, there was a job loss in the province during this period (Table 01). Nearly sixty percent of the industry groups have reported negative growth rates representing a job loss while only 42 percent of industries have an increased number of jobs. The largest job loss has been reported by the manufacturing industry while the largest job gain has been reported by the industry group of construction, electricity, gas, steam and air conditioning supply, water supply, sewerage, waste management, and remediation activities. However, many industries have declined during this period and the ultimate result was that the region has lost 38994 jobs by the year 2018. This job changes (-38994) was decomposed by the Shift Share analysis into NS, IM, and RS components, and results obtained in this connection are shown in Table 02 and Figure 01.

Table 02: Results of the Shift Share Analysis in the Sabaragamuwa Province, 2013-2018

\begin{tabular}{|c|c|c|c|c|}
\hline Industrial Sector & $\begin{array}{l}\text { National Trend } \\
\text { (NS) }\end{array}$ & $\begin{array}{l}\text { Industry Trend } \\
\text { (IM) }\end{array}$ & $\begin{array}{l}\text { Regional } \\
\text { Performance } \\
\quad(\mathbf{R S})\end{array}$ & $\begin{array}{l}\text { Total net Change } \\
\text { 2013-2018 }\end{array}$ \\
\hline Agriculture, Forestry and Fishery & -13411.85 & -38209.67 & 55850.52 & 4229 \\
\hline Mining \& Quarrying & -1832.13 & -12721.32 & 7268.45 & -7285 \\
\hline Manufacturing & -8721.79 & 2679.88 & -21585.08 & -27627 \\
\hline $\begin{array}{l}\text { Construction, Electricity, Gas, steam and air conditioning } \\
\text { supply, Water supply, sewerage, waste management and } \\
\text { remediation activities }\end{array}$ & -2218.34 & 12132.24 & 14489.10 & 24403 \\
\hline $\begin{array}{l}\text { Wholesale and Retail Trade, Repair of Motor Vehicles } \\
\text { and Motor cycles }\end{array}$ & -4508.13 & 3729.83 & 1031.30 & 253 \\
\hline Transportation and Storage & -2685.46 & 1014.78 & -6839.33 & -8510 \\
\hline Accommodation and food service activities & -681.48 & 4464.28 & -5478.80 & -1696 \\
\hline Information and Communication & -170.41 & -252.00 & -1969.59 & -2392 \\
\hline Financial and Insurance activities & -293.74 & 1109.30 & 3601.44 & 4417 \\
\hline Professional Scientific and technical activities & -229.23 & 1522.43 & -547.19 & 746 \\
\hline Administrative and support service activities & -307.84 & 3916.32 & 848.52 & 4457 \\
\hline $\begin{array}{l}\text { Public administration and defense compulsory social } \\
\text { security }\end{array}$ & -2043.54 & -11203.83 & 3393.38 & -9854 \\
\hline Education & -1520.47 & 10742.29 & -11848.83 & -2627 \\
\hline Human health and social work & -669.01 & 851.78 & -3611.77 & -3429 \\
\hline Other Service Activities & -455.12 & -645.27 & -436.61 & -1537 \\
\hline $\begin{array}{l}\text { Activities of households as employers; undifferentiated } \\
\text { goods and services-providing activities of households for } \\
\text { own use }\end{array}$ & -1556.41 & 3705.26 & -14959.85 & -12811 \\
\hline Other & -125.58 & 421.41 & -26.83 & 269 \\
\hline Total employment & -41430.53 & 0 & 2436.53 & -38994 \\
\hline
\end{tabular}

Source: Data Analysis, 2020 
International Journal of Humanities and Applied Social Science (IJHASS)

E-ISSN: 2471-7576

October 2020, Vol: 5, Issue: 10

E-mail: editor@ijhassnet.com

http://ijhassnet.com/

DOI: 10.33642/ijhass.v5n10p1

CCenter for Promoting Education and Research (CPER) USA,www.cpernet.org

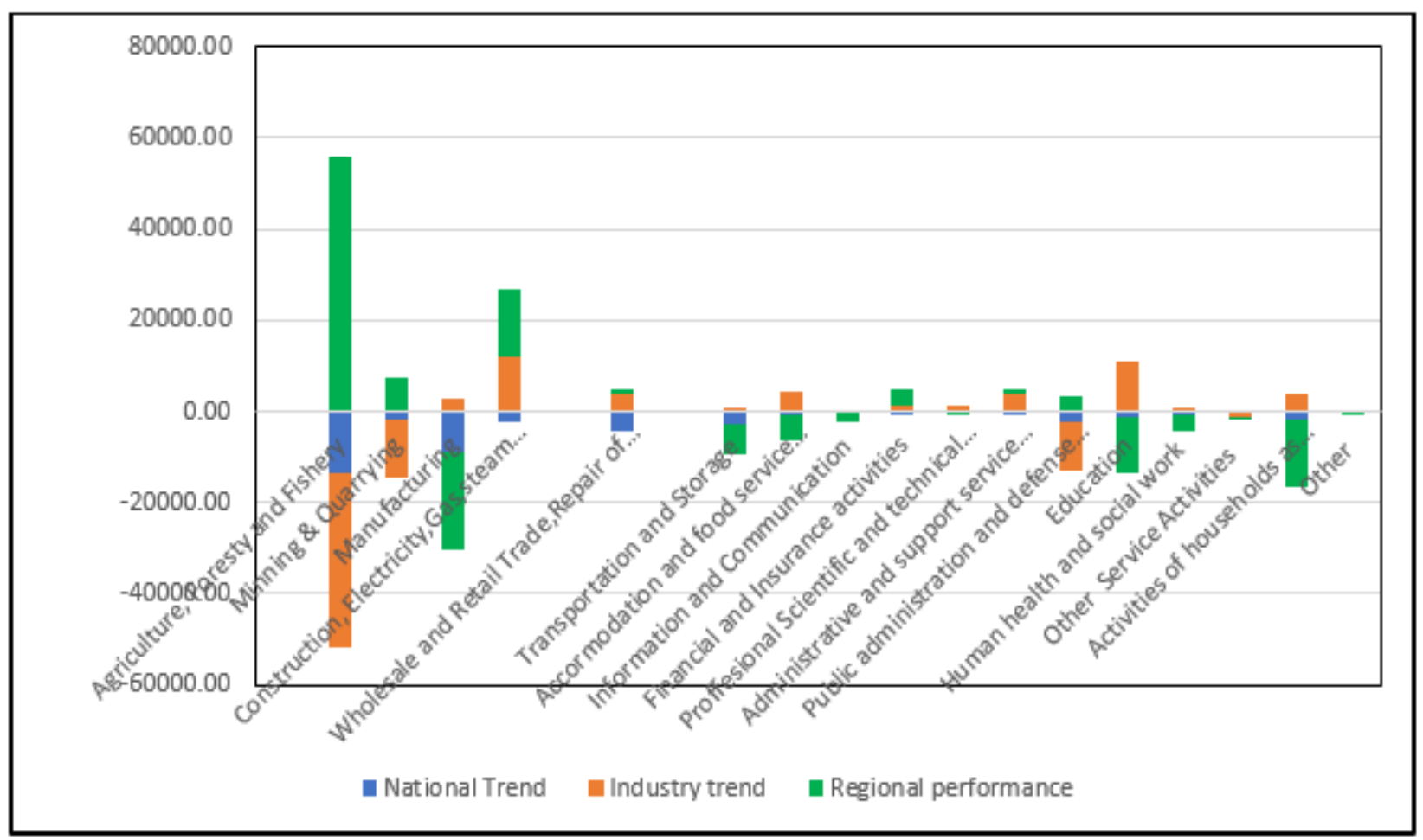

Figure 01: National Trend, Industry Trend and Regional Share in the Sabaragamuwa Province, 2013-2018

Source: Data Analysis, 2020

Turning to the National Share (NS) effect, which is the effect of the overall national growth on the growth of the relevant region. According to the results of the NS component during the reference period (2013-2018), there was a job loss in all the industry sectors in the province (NS column-Table 02) since the overall national growth rate (4.78) was mines. (Column 8-Table 01). During this period The Sabaragamuwa province has lost 41431total number of jobs as a result of this negative growth effect of the national economy. During this period, Sri Lanka has not performed a satisfactory economic growth rate due to the negative growth rates of 7 industry groups out of 17 (41 percent of industries) and this is the main reason to have a negative growth rate of the national economy (Table 01). Several important industry groups in the country have extremely undergone a decline and it seems that they were the highly responsible contributors for this situation. The agriculture, Forestry, and Fishery sector have a great role in the economic development of the county but, its significance in terms of yield and employment is continuously going down (Central Bank of Sri Lanka, 2019). This situation is observable even in the reference period of the analysis with the -18.39 percent decline nationally. In the same way, the effect of the serious decline of the mining sector by -37.96 percent and public administration and defense compulsory social security by-30.98 percent also is responsible for the poor economic performance in the national economy of the county during this period.

In this context, it can be seen that the Sabaragamuwa Province is strongly hit by the effect of the negative economic growth of the country. Agriculture, forestry and fishery, manufacturing and wholesale and retail trade, repair of motor vehicles and motorcycles, and transportation and storage were the extremely declining industry groups losing a large number of jobs due to the effect of minus growth of the national economy. Therefore, from 2013 to 2018 National Share was extremely unfavorable for the employment growth of the Sabaragamuwa Province.

The second column of Table 02 shows the Industry Mix (IM) effect of the Sabaragamuwa Province due to the change that occurred in the industries nationwide during the reference period. According to the resulting values, the industry mix effect has been positive for many industries in the province. Though NS was not favorable for the employment growth of the province, the industry mix effect is positive for many industry sectors which indicates the change occurred in the industries nationwide during the reference period has made a favorable situation for the job growth in the province. 12 industry groups (70 percent) of the province have grown with new jobs and only 5 industry groups (30 percent) have weakened during this period. Construction, electricity, gas, steam and air 
conditioning supply, water supply, sewerage, waste management, and remediation activities, education and accommodation and food service activities, administrative and support service activities, wholesale and retail trade, repair of motor vehicles and motorcycles were the major industry groups which maintained a fast growth due to the favorable condition of the IM effect. Agriculture, forestry and fishery, mining \& quarrying, and public administration and defense compulsory social security where the main industry groups which have declined in the province due to the harmful effect of IM. These industry groups were negatively performing with declining growth rates nationally also during this period. However, the IM effect was considered favorable for the employment growth in the province.

Column three of Table 02 shows the Regional Share (RS) of the employment change in the province. As the analysis reveals that as a whole, during the reference period the province itself has performed fairly well in terms of its growth. Province has saved a 2436.53 number of jobs and it is a positive fact to prove the region is slightly completive having certain unique conditions and advantages to save the jobs. However, it seems that only a few industries have contributed to the competitiveness of the region. In this regard, only 7 individual industry groups (41 percent) can be identified as high-performing industries generating a large number of jobs due to the favorable conditions within the region. The agriculture, forestry, and fishery sector which declined with a huge job loss in terms of NS and IM components is the best performing industry in the region achieving 55850.52 new jobs. Also, construction, electricity, gas, steam, and air conditioning supply, water supply, sewerage, waste management, and remediation activities, mining \& quarrying, financial and insurance activities, and public administration and defense compulsory social security sectors are competitive industries generating a considerably higher number of jobs at the region level. The positive growth of these industries is the main factor that contributed to the general prosperity of the region during this period.

Even though, as shown by the results during the reference period condition of the region was not good for a large number of industry groups. In this regard, 12 industry groups (59 percent) can be identified as backward industries at the regional level. Industries such as, activities of households as employers; undifferentiated goods and services-providing activities of households for own use, manufacturing, education, transportation and storage, and accommodation and food service activities have declined to lose a great number of jobs during this period. It means that the region does not provide a better background for the growth of these industries.

\section{Conclusion}

As the Shift Share analysis reveals the Sabaragamuwa Province was not performing well in recent years in the overall context, but there are some positive points. As shown by the results national contribution to regional growth is extremely unfavorable leading to a huge loss of total jobs regionally. This effect is worse for the agricultural and manufacturing sectors than the other industrial categories. However, there are some positive changes in employment in some industry groups due to the IM effect and the RS effect. 70 percent of industries in the region have been benefited by the positive IM effect and the agriculture and mining and quarrying sectors which are the main pillars in the province that have seriously impacted by the negative industrial mix effect. RS effect which is the regional competitiveness also is fairly good because the region has saved the total employment of 2436.53. The region is satisfactory only for 7 industry groups but their job gain is concededly higher. Agriculture, forestry, and fishery sector is the most leading industry at the regional level while the manufacturing industry is the most backward industry sector in the region. Leading industries with the competitive advantage of the province such as agriculture, mining, construction should be further strengthened while backward industries like manufacturing, transport, education should be empowered to become effective industries.

Looking at the entire picture of Shift Share analysis, it is obvious that strong policy intervention is needed to guide not only the provincial growth but also the national growth. Regional policies and planning actions are the tools that involve guiding the development of a region. Generally, a regional policy of a country arises as a result of two reasons. One is growing problems of regional inequalities and the other is to promote overall national development by enhancing the potentials of different regions. Today, the purpose of regional development has changed. Today, it concerns not only the elimination of disparities between regions but also on building competitive regions to meet the challenges of the global economy and creating dynamic territorial units to accommodate the needs of a society that is influenced by the forces of globalization. However, Sri Lanka has been implementing many development policies at the national as well as regional level but, the success of these policies is questionable with this minus growth. 
Therefore, a new policy agenda addressing the weak points of the national economy and promote the specific advantages of each region is a vital requirement to boost up both regional and national economy.

\section{References}

Andrikopoulos, A., J. Bronx, and E. Carvalho. (1990). Shift-Share Analysis and the Potential for Predicting Regional Growth Patterns: Some Evidence for the Region of Quebec, Canada. Growth and Change, 21 (1), 1-10 Capello, Roberta. (2009). Regional Growth and Local Development Theories: Conceptual Evolution over Fifty Years. Regional Science, Geography, Economy, Society, 2009/1, Vol. 11, 9-21

Central Bank of Sri Lanka, (2019). Central Bank Report

Chun-Yun Shi and Yang Yang, (2008), A Review of Shift Share Analysis and Its Application in Tourism Available at https://www.researchgate.net/publication/267765154, Accessed on 11 August 2020

Department of Census and Statistics, (2013). Annual Report of Labor Force Survey

Department of Census and Statistics, (2014). Annual Report of Labor Force Survey Friedmann, John. (1970). Regional Development Policy: A Case Study on Venezuela. M.I.T. Press. London

Dunn, E. S. (1960). A statistical and analytical technique for regional analysis. Paper presented at the Papers and Proceedings of the Regional Science Association.

Kurre, J. A., and B. R. Weller (1989). Forecasting the Local Economy, Using Time Series and Shift-Share Techniques. Environment and Planning, 21 (6), 753-70

Knudsen, D. C. (2002). Shift-Share Analysis: Further Examination of Models for the Description of Economic Change. Socio-Economic Planning Sciences, 34(3), 177-198

Nazara, S., \& Hewings, G. J. D. (2004). Spatial Structure and Taxonomy of Decomposition in Shift-Share Analysis. Growth and Change, 35(4), 476-490

Mead, A. C., and G. A. Ramsay (1982). Analyzing Differential Responses of a Region to Business Cycles. Growth and Change, 13 (1), 38-42

Moore, M. (1984) Categorizing Space: Urban-Rural or Core-Periphery in Sri Lanka in John Harris and Mick Moore, (Ed), Development and the Rural-Urban Divide, Frank Cass and Company Limited, London

Sabaragamuwa Provincial Council, (2018). Five-Year Vision Oriented Integrated Development Plan, 2019-2023

Samarasinghe, V. (1984). Government Policy and Regional Development in Sri Lanka, Paper Presented at the Seminar on Staff Studies (9th March) University of Peradeniya, Sri Lanka

Wanasinghe, Y.A.D.S. (2001). Regional Imbalances in Sri Lanka: A Critique of Regional Development Policies and Strategies in M. M. Karunanayake (ed) People, Space and Resources: Perspectives on Development Issues in Rural Sri Lanka, Department of Geography, University of Sri Jayewardenepura-Sida/SAREC Research Cooperation Project

Wijerathna, Deeptha, Bandara, Jayatilleke S., Smith, Christine and Naranpanawa, Athula (2014). Regional

Disparities in Sri Lanka: An Empirical Analysis. Asia-Pacific Development Journal vol. 21, no. 2, 77-102

Wijedasa, M.B. (1992). Spatial Patterns in Socio-Economic Well-being in Sri Lanka. Malaysian Journal of Geography, (June)

Yasin, M., Alavi, J., Sobral, F., \& Lisboa, J. (2004). A Shift-Share Analysis Approach to Understanding the Dynamic of the Portuguese Tourism Market. Journal of Travel \& Tourism Marketing, 17(4), 11-22 